Berkala Ilmu Perpustakaan dan Informasi, Vol. 13, No. 2, Desember 2017, Hal. 166-177 DOI: http:// 10.22146/bip.27492

ISSN 1693-7740 (Print), ISSN 2477-0361 (Online)

Tersedia online di https://jurnal.ugm.ac.id/bip

\title{
KOLABORASI INTERNAL, DOMESTIK DAN INTERNASIONAL SERTA KORELASINYA DENGAN SITASI YANG DIPEROLEH: ANALISIS PUBLIKASI UGM DI SCOPUS
}

\author{
Maryono dan Surajiman ${ }^{1}$ \\ 'Pustakawan Universitas Gadjah Mada \\ e-mail: masyono@ugm.ac.id
}

Naskah diterima: 15 Agustus 2017, direvisi: 20 September 2017, disetujui: 13 Oktober 2017

\begin{abstract}
ABSTRAK
Penelitian ini dilatarbelakangi oleh adanya berbagai regulasi tentang kewajiban publikasi di jurnal internasional bagi dosen, mahasiswa doktoral dan peneliti. Fokus analisis pada aspek kolaborasi publikasi berafiliasi UGM di Scopus tahun 1954 sampai dengan 2016, menggunakan metode bibliometrik dan korelasi. Beberapa temuan penting berhasil didapatkan. Kolaborasi internasional memperoleh sitasi jauh lebih banyak dibandingkan kolaborasi lain dan karya individu. Sitasi kolaborasi internasional sejumlah 22.431, dengan rerata 11,8432. Sitasi kolaborasi internal sejumlah 2.072, dengan rerata 1,9328. Sitasi kolaborasi domestik sejumlah 1.458, dengan rerata 1,4609. Sitasi karya individu sejumlah 1.014, dengan rerata 3,6344. Negara kolaborator penghasil sitasi tertinggi adalah Jepang, sejumlah 5.242 sitasi, dengan rerata 12,31. Disusul USA sejumlah 4.503 sitasi, dengan rerata 26,49. Kemudian Netherlands sejumlah 4.057 sitasi, dengan rerata 18,69. Publikasi individu tidak berkorelasi dengan sitasi yang diperoleh, sedangkan publikasi karya kolaborasi semuanya berkorelasi positif. Kolaborasi internasional diperkirakan akan memiliki korelasi sempurna sebesar +1 pada akhir dasawarsa 20102019.
\end{abstract}

Kata kunci: Bibliometrik, kolaborasi internasional, jurnal internasional, sitasi, Scopus

\begin{abstract}
This research is motivated by the several new regulations on publication obligations in international journals for lecturers, doctoral students and researchers. The focus of analysis in this paper is on UGM collaborations in publications in Scopus from 1954 to 2016, using bibliometrics and correlations. The findings show that international collaborations received more citations than any other collaborations and individual work. International collaboration received 22.431, with average of 11,8432. internal collaboration is 2.072; 1,9328. Domestic collaboration is 1.458, 1,4609. individual work is 1.014; 3,6344. The country's largest citation producer collaborator is Japan, some 5.242, with average of 12,31. Followed by USA 4.50; 26,49, then the Netherlands 4.057, 18, 69. Individual publications are not correlated with the citation obtained, while the publication of the collaborative works are all positively correlated. International collaboration is expected to have a perfect correlation of +1 by the end of the decade 2010-2019.
\end{abstract}

Keywords: Bibliometrics, international collaboration, international journal, citation, scopus 


\section{A. PENDAHULUAN}

Publikasi ilmiah adalah bentuk komunikasi i $1 \mathrm{miah}$, yang ditujukan untuk mengkomunikasikan dan menyebarkan informasi hasil-hasil penelitian. Penyebaran informasi ilmiah kepada masyarakat luas, serta khususnya masyarakat ilmuwan sejawat. Dosen, peneliti dan mahasiswa doktoral wajib mempublikasikan hasil-hasil penelitiannya ke jurnal internasional. Kewajiban dosen yang menduduki jabatan lektor kepala untuk mempublikasikan karya ilmiah di jurnal internasional, serta guru besar atau profesor di jurnal internasional yang bereputasi, ditegaskan melalui Peraturan Menteri Pendidikan dan Kebudayaan Republik Indonesia Nomor 92 Tahun 2014. Demikian juga peneliti yang menduduki jenjang profesor riset wajib mempublikasikan hasil penelitiannya dalam jurnal internasional bereputasi, telah ditegaskan dalam Peraturan Kepala Lembaga Ilmu Pengetahuan Indonesia Nomor 9 Tahun 2015. Sedangkan mahasiswa doktoral, kewajiban tersebut ditegaskan. dalam Surat Edaran Dirjen Dikti No.152/E/T/2013 tanggal 27 Januari 2012. Meskipun jumlah perguruan tinggi di Indonesia cukup besar, yaitu 4.492 PTN dan PTS aktif (Dikti, 2017), dalam hal kinerja publikasi ilmiah di jurnal internasional, Indonesia masih tertinggal dibandingkan negara-negara maju, bahkan negara tetangga sekalipun. Menurut data dari Scimago (2017), posisi Indonesia berada pada urutan 57, masih di bawah Singapura di urutan 32, Malaysia urutan 35 dan Thailand di urutan 43. Dengan berbagai regulasi tersebut, pemerintah berharap dapat meningkatkan kualitas penelitian dan kinerja publikasi setara dengan negara maju.

Perkembangan saat ini terdapat dua database jurnal terbesar, yaitu Web of Science (WOS) dan Scopus. Keduanya merupakan pengindeks jurnal serta prosiding dan paten, mencakup data bibliografi, abstrak dan sitasi. Menurut WOS (2017), WOS kini mengelola lebih dari 12.000 jurnal, 160.000 prosiding dan 26 juta paten. Sedangkan Scopus, menurut Servellen (2016), mengelola \pm 22.245 jurnal, \pm 90.000 prosiding, serta \pm 25 juta paten. Meskipun mengelola terbitan lebih sedikit, tetapi WOS memiliki kelebihan dalam hal seleksi yang lebih ketat (Kim, 2015). WOS juga memiliki data sitasi pada rentang waktu terbitan antara tahun 1900 sampai dengan 1964 yang lebih lengkap (Wagner, 2015). Tetapi studi yang dilakukan oleh Chadegani (2013), dan Kim (2015) menunjukkan bahwa sebagian besar jurnal yang dikelola oleh Web of science, juga dikelola oleh Scopus. Sehingga untuk pertimbangan efisiensi anggaran, melanggan Scopus dianggap sudah memadai.

Berdasarkan data Scopus (2017), total publikasi pengarang yang berafiliasi Universitas Gadjah Mada (UGM) berjumlah 4.767 dokumen. Publikasi tersebut memiliki rentang terbit di mulai dari tahun 1954 sampai dengan tahun 2017. Sebagian publikasi telah memperoleh sitasi, sebagian lagi belum memperoleh. Sitasi menunjukkan dampak ilmiah suatu publikasi, sehingga sangat penting dikaji.

\section{Permasalahan}

Belum diketahui hubungan (korelasi) antara kolaborasi peneliti berafilisasi UGM dengan perolehan sitasi. Demikian juga jumlah perolehan sitasi kolaborasi internal, domestik, dan internasional, serta individu. Kemudian negara mana yang menjadi kolaborator dengan sitasi terbanyak.

\section{Tujuan Penelitian}

Tujuan Penelitian ini yaitu: 1) Mengetahui perbedaan jumlah sitasi yang diperoleh publikasi karya kolaborasi internal, domestik, internasional dan individu 2) Menentukan besarnya hubungan korelasi antara publikasi kolaborasi internal, domestik, internasional, dan individu dengan jumlah sitasi yang diperoleh 3) Mengetahui negara kolaborator yang memperoleh sitasi tertinggi

\section{B. TINJAUAN PUSTAKA Penelitian Terdahulu}

Wulandari (2013) melakukan analisis kolaborasi terhadap database IPBana 1978 sampai dengan 2007 untuk berbagai disiplin ilmu, dan dibagi ke dalam 3 periode waktu. Penelitian tersebut menentukan adanya 
korelasi antara tingkat kolaborasi dengan produktivitas penelitian. Ibanez (2013), menganalisis artikel bidang ilmu komputer dalam Web of Science antara 2000-2009. Ditemukan bahwa sebagian besar artikel disusun oleh kolaborasi 3 pengarang. Sooryamurthy (2017), menganalisis data artikel dari Afrika Selatan pada Social Science Citation Index dari Web of Science kurun waktu 1970 sampai dengan 2015. Kolaborasi regional dengan sesama negara Afrika, tidak menghasilkan sitasi secara signifikan. Penelitian ini berbeda dengan penelitian terdahulu, menganalisis kolaborasi peneliti berafiliasi UGM di Scopus dimulai 1954 sampai dengan 2016, dan merincinya ke dalam kategori internal, domestik dan internasional serta menghitung korelasinya dengan sitasi yang diperoleh. Melalui penelitian ini dapat diperoleh gambaran seberapa besar dampak ilmiah peneliti UGM dan seberapa kuat hubungan antara kolaborasi internal, domestik dan internasional dengan sitasi yang diperoleh dalam database Scopus.

\section{Kriteria Jurnal Internasional}

Lampiran Peraturan Menteri Riset, Teknologi, dan Pendidikan Tinggi Nomor 20 Tahun 2017 menjelaskan Jurnal Internasional adalah jurnal yang memenuhi kriteria sebagai berikut: karya ilmiah yang diterbitkan ditulis dengan memenuhi kaidah ilmiah dan etika keilmuan; memiliki ISSN; ditulis dengan menggunakan bahasa resmi PBB (Arab, Inggris, Perancis, Rusia, Spanyol, dan Tiongkok); memiliki terbitan versi online; dewan Redaksi (Editorial Board) adalah pakar di bidangnya paling sedikit berasal dari 4 (empat) negara; artikel ilmiah yang diterbitkan dalam 1 (satu) nomor terbitan paling sedikit penulisnya berasal dari 2 (dua) negara.

\section{Prosiding}

Lampiran Peraturan Menteri Riset, Teknologi, dan Pendidikan Tinggi Nomor 20 Tahun 2017 juga menjelaskan bahwa karya ilmiah pada prosiding internasional yang terindeks basis data internasional (Web of Science, Scopus) dinilai sama dengan jurnal internasional dengan kriteria sebagai berikut: diselenggarakan oleh asosiasi profesi, atau perguruan tinggi, atau lembaga ilmiah yang bereputasi; steering committee (Panitia Pengarah) terdiri dari para pakar yang berasal dari berbagai negara; ditulis dalam bahasa resmi PBB (Arab, Inggris, Perancis, Rusia, Spanyol dan Tiongkok); editor berasal dari berbagai negara sesuai dengan bidang ilmunya; Penulis paling sedikit berasal dari 4 (empat) negara; dan Memiliki ISBN.

\section{Jurnal Internasional Bereputasi}

Jurnal Internasional bereputasi adalah yang memenuhi kriteria jurnal internasional sebagaimana tersebut di atas, dengan indikator: diterbitkan oleh asosiasi profesi ternama di dunia atau perguruan tinggi atau penerbit ( $\mathrm{p} u$ blisher) kredibel; terindeks oleh pemeringkat internasional yang diakui oleh Kementerian Riset, Teknologi, dan Pendidikan Tinggi (contoh Web of Science dan/atau Scopus) serta mempunyai faktor dampak (impact factor) lebih besar dari 0 (nol) dari ISI Web of Science (Thomson Reuters) atau mempunyai faktor dampak (SJR) dari SCImago Journal and Country Rank paling rendah Q3 (quartile tiga); alamat jurnal dapat ditelusuri daring; editor boards dari jurnal dapat ditelusuri daring dan tidak ada perbedaan antara editor yang tercantum di edisi cetak dan edisi daring; proses review dilakukan dengan baik dan benar; jumlah artikel setiap penerbitan adalah wajar dan format tampilan setiap terbitan tidak berubahubah; tidak pernah diketemukan sebagai jurnal yang tidak bereputasi atau jurnal meragukan oleh Direktorat Jenderal Sumber Daya Ilmu Pengetahuan, Teknologi, dan Pendidikan Tinggi; dan Jurnal Ilmiah Nasional terakreditasi A dari Kementerian Riset, Teknologi, dan Pendidikan Tinggi yang diterbitkan dalam salah satu bahasa PBB, terindeks di DOAJ dengan indikator green thick (centang dalam lingkaran hijau) disetarakan/diakui sebagai jurnal internasional.

\section{Sitasi ( citation) \\ International encyclopedia of information and libraryscience (2003), menjelaskan sebagai}


berikut "citation are notes placed in the main text of an academic publication that give a bibliographic reference to published work which has been used or quoted by the author". Semakin tinggi jumlah sitasi yang diperoleh suatu dokumen, menunjukkan tingginya manfaat dokumen tersebut, dan disebut semakin berkualitas. Demikian juga suatu jurnal, semakin tinggi jumlah sitasi yang diperoleh, semakin tinggi kualitasnya, dan memiliki faktor dampak (impact factor) dan peringkat yang tinggi.

\section{Kolaborasi Penelitian}

Dalam penelitian dan publikasi dikenal istilah kolaborasi, yaitu kerjasama antara dua orang atau lebih untuk melakukan penelitian dan mempublikasikannya. Kolaborasi dilakukan dengan berbagai alasan yang ditujukan untuk meningkatkan kualitas dan kinerja. Kolaborasi terjadi baik antar peneliti dalam satu institusi, antar institusi, maupun antar negara dari disiplin ilmu yang berbeda. Kolaborasi penting dilakukan, karena tidak mungkin meneliti permasalahan yang sangat kompleks hanya seorang diri, ataupun dengan sumberdaya dan sarana yang sangat terbatas. Katz dan Martin (1997) menjelaskan bahwa kolaborasi riset dapat didefinisikan sebagai kerjasama antara peneliti untuk mencapai tujuan memproduksi pengetahuan ilmiah baru. Kolaborasi dalam penelitian berlangsung bila dua peneliti atau lebih bekerja sama, dalam sebuah kegiatan, masing-masing memberikan sumbangan sumber daya dan usaha baik intelektual maupun fisik. Menurut Beaver (2001) kolaborasi bisa terjadi secara kebetulan, pada saat kolokium, perkuliahan, konferensi, presentasi, tugas bersama, ataupun saat kunjungan kerja. Kolaborasi juga bisa terjadi secara sengaja, dengan permohonan melalui email ataupun telepon. Kolaborasi juga bisa terjadi melalui rekomendasi atau rujukan dari kolega. Kolaborasi biasanya terdiri dari 2 atau 3 individu, kadang lebih, dan merupakan sejawat (peers).

\section{Tujuan Kolaborasi Penelitian}

Beaver (2001) lebih lanjut menyebutkan 18 tujuan dilakukannya kolaborasi. Pertama, mengakses keahlian yang dibutuhkan. Kedua, mengakses peralatan, sumberdaya dan bahanbahan yang tidak/belum dimiliki. Ketiga, meningkatkan akses ke sumber pendanaan. Keempat, memperoleh kebanggaan (prestige) dan visibilitas, dalam rangka peningkatan profesionalisme. Kelima, demi efisiensi, karena dengan menggabungkan beberapa tenaga, pikiran dan pengetahuan. Keenam, untuk memacu kemajuan lebih cepat. Ketujuh, untuk menangani permasalahan yang lebih besar, lebih penting, lebih komprehensif, tingkat kesulitan lebih tinggi, serta permasalahan global. Kedelapan, untuk meningkatkan produktivitas penelitian. KeSembilan, untuk mengenal lebih banyak orang, serta menciptakan jaringan. Kesepuluh, untuk mempelajari peralatan baru, keahlian baru, bidang spesifik yang baru, atau permasalahan baru. Kesebelas, untuk memuaskan rasa keingintahuan dan minat intelektual. Kedua belas, untuk berbagi kebahagiaan dengan orang lain. Ketiga belas, untuk menyempurnakan penelitian dengan lebih efisien, mengurangi kesalahan (errors, mistakes). Keempat belas, untuk menjaga seseorang tetap fokus pada penelitian, karena ada partner yang mengerjakan pekerjaan lainnya. Ke limabelas, untuk mengurangi keterkucilan, meningkatkan energi dan semangat meneliti. Keenam belas, untuk mendidik mahasiswa, sarjana, ataupun diri sendiri. Ketujuh belas, untuk belajar dan meningkatkan pengetahuan. Kedelapan belas, untuk hiburan dan kesenangan.

\section{Jenis Kolaborasi Penelitian}

Menurut Sangam (2000), Kolaborasi dapat dibedakan menjadi 3 jenis. Pertama, kolaborasi internal, dalam departemen yang sama, antar departemen, dalam institusi yang sama. Kedua, Kolaborasi domestik, kolaborasi antara dua institusi atau lebih dalam sebuah negara. Ketiga, kolaborasi antara institusi, terdiri dari dua 
negara atau lebih. Kolaborasi internal pada umumnya lebih banyak dilakukan, menyusul kolaborasi domestik. Sedangkan kolaborasi internasional lebih jarang dilakukan, meskipun jumlahnya cenderung mengalami peningkatan.

\section{Kolaborasi Penelitian dan Produktivitas Publikasi}

Kolaborasi penelitian pada umumnya berpengaruh terhadap produktivitas publikasi. Sesuai dengan temuan Hu (2014), bahwa pada bidang disiplin ilmu tertentu terdapat korelasi yang lebih kuat. Semakin tinggi tingkat kolaborasi, semakin meningkat jumlah produktivitas publikasi. Studi oleh Cainelli dkk (2014) juga menunjukkan adanya pengaruh beberapa atribut kolaborasi terhadap produktivitas. Atribut tersebut di antaranya adalah usia, gender, posisi akademik, masa jabatan, serta lokasi geografis.

\section{Kolaborasi Penelitian dan Kualitas Publikasi}

Studi oleh Low dkk (2014), dan juga oleh Nguyen dkk (2017) menunjukkan bahwa kolaborasi internasional berkaitan dengan tingginya jumlah sitasi yang diperoleh dan faktor dampak (impact factor). Pada umumnya semakin banyak kolaborasi internasional yang dilakukan, semakin banyak sitasi yang diperoleh, semakin tinggi kualitas serta visibilitas artikel dan jurnal.

\section{METODE PENELITIAN}

Jenis penelitian yang digunakan adalah bibliometrik dan juga korelasi. Bibliometrik untuk mendeskripsikan dan mengeksplorasi berbagai jenis kolaborasi dan sitasi yang diperoleh. Sedangkan korelasi untuk melihat besarnya hubungan antara kolaborasi dengan jumlah sitasi yang diperoleh. Menurut SulistyoBasuki (2002), bibliometrika terbagi atas dua kelompok besar yaitu yang mengkaji distribusi publikasi dan kelompok yang membahas analisis sitiran/sitasi (citation analysis). Kelompok pertama merupakan analisis kuantitatif terhadap literatur dengan tiga "dalil" dasar bibliometrika yaitu dalil Lotka (1926), dalil Zipf (1933), serta Bradford's law of scattering. Sedangkan menurut Sugiyono (1999), untuk menguji hipotesis adanya hubungan asosiatif dengan data urut (ordinal), berjenjang atau ranking dapat digunakan metode korelasi Spearman Rank.

\section{Populasi}

Populasi dalam penelitian ini adalah artikel yang berafiliasi dengan UGM dalam database Scopus pada kurun waktu tahun 1954 sampai dengan tahun 2016. Penelitian ini adalah penelitian populasi, sehingga tidak dilakukan pengambilan sampel. Penulis memilih periode 1954 sampai dengan 2016 sebagai populasi, karena pada kurun waktu tersebut telah cukup waktu untuk memperoleh sitasi. Sedangkan tahun 2017 meskipun ada yang telah memperoleh sitasi, tetapi masih terlalu singkat untuk memperoleh sitasi.

\section{Teknik Pengumpulan Data}

Pada penelitian ini pengumpulan data menggunakan metode dokumentasi. Data diperoleh dari database Scopus, yaitu semua publikasi berafiliasi UGM pada kurun waktu 1954 sampai dengan 2016. Selanjutnya langkah-langkah yang dilakukan dalam pengumpulan data adalah sebagai berikut:

\section{Mengumpulkan semua data sitasi dari Scopus.}

Pada tanggal 1 Mei 2017 dilakukan advanced search, data antara tahun 1954 sampai dengan 2016 dengan alamat scopus.com, menggunakan metode advanced search dengan syntax penulisan sebagai berikut:

"AFFIL (gadjah AND mada) OR AFFIL( ugm) OR AFFIL (gadjah) OR AFFIL (mada ) $A N D$ (EXCLUDE ( PUBYEAR, 2017)) AND ( LIMIT-TO ( DOCTYPE, "ar" ) OR LIMIT-TO (DOCTYPE, "cp") OR LIMIT-TO (DOCTYPE, "ip"))“

Dengan syntax tersebut dilakukan proses pembatasan (limit to), hanya untuk jenis dokumen artikel (article), artikel dalam proses terbit (article in press), prosiding (conference paper), dan mengecualikan tahun terbit 2017, sehingga dihasilkan sejumlah 4.295 dokumen. Dokumen tersebut terdiri dari 3.125 artikel 
jurnal internasional, disusul 1.126 prosiding, dan 44 artikel dalam proses terbit. Data yang digunakan adalah 3 jenis dokumen tersebut. Pertimbangan yang digunakan adalah bahwa jenis karya yang dipilih tersebut sesuai dengan bunyi Lampiran Peraturan Menteri Riset, Teknologi, Dan Pendidikan Tinggi Nomor 20 Tahun 2017.

\section{Ekspor Data dan Modifikasi Kolom Tabel}

Memeriksa setiap publikasi hasil search, dan melakukan proses ekspor data sitasi ke dalam bentuk csv (excell). Setelah diperoleh data tabel csv, dilakukan modifikasi kolom tabel menjadi sebagai berikut: (1) Nomor (2) kolom tahun (3) kolom judul publikasi (4) negara (5) jumlah penulis kolaborasi (6) internal (7) domestik (8) internasional (9) jumlah sitasi:

Tabel 1 Data Sitasi (master data)

\begin{tabular}{|c|c|c|c|c|c|c|c|c|}
\hline & Tahun & $\begin{array}{c}\text { Judul } \\
\text { Publikasi }\end{array}$ & Negara & $\begin{array}{l}\text { Jum lah } \\
\text { Penulis } \\
\text { Kolaborasi }\end{array}$ & Internal & Domestik & Internasional & $\begin{array}{l}\text { Jum lah } \\
\text { Sitasi }\end{array}$ \\
\hline
\end{tabular}

\section{Menyempurnakan Data}

Setelah tabel dimodifikasi, dilakukan penyempurnaan data dengan melakukan cek ulang dan entri pada kolom data yang belum sempurna. Berdasarkan langkah-langkah tersebut, diharapkan perolehan data dapat dijamin kecermatan dan ketepatannya.

\section{Metode Analisis Data}

Setelah data terkumpul kemudian dilakukan kegiatan analisis data yang terdiri beberapa tahap: 1) Mengurutkan data secara bertingkat pada beberapa kolom untuk mendapatkan informasi yang diperlukan. 2) Membagi kolom tahun menjadi 7 periode 19541959, 1950-1969, 1970-1979, 1980-1989, 1990-1999, 2000-2009 dan 2010-2016, serta melakukan penghitungan korelasi dengan Uji Korelasi Spearman Rank 8) Masing-masing data dan tabel dianalisis, dan dibuatkan grafik seperlunya

\section{Uji Korelasi Peringkat Spearman Rank}

Menurut Sugiyono (1999), untuk menghitung korelasi antara data berurutan (ordinal), berjenjang atau ranking dan bebas distribusi dapat digunakan rumus korelasi Spearman Rank:

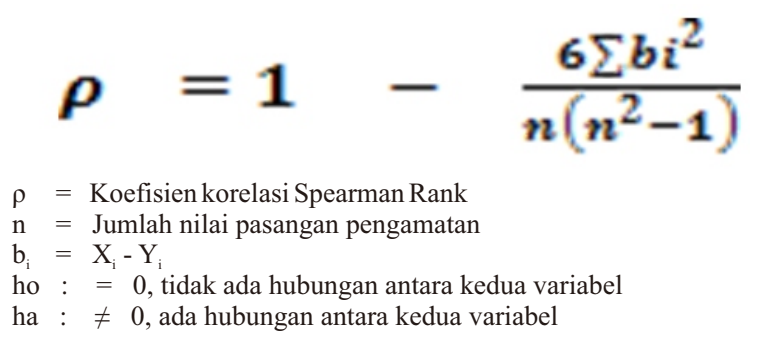

Murti (1996) menjelaskan bahwa koefisien korelasi Spearman dimaksudkan untuk menguji kemaknaan hubungan. Terdapat 3 kemungkinan hubungan. Pertama, kedua variabel sama sekali tidak berkorelasi. Ke dua, variabel berkorelasi positif. Ke tiga, kedua variabel berkorelasi negatif. Oleh karena itu koefisien korelasi bernilai antara -1 dan +1 . Jika nilai koefisien $=0$ tidak terdapat korelasi, dan 0 terdapat korelasi. Jika nilai $\mathrm{n}$ antara 4 dan 30 , bandingkan nilai $\rho$ dengan nilai kritis dalam tabel koefisien korelasi. Keputusan diambil dari perbandingan tersebut. Hipotesis $\mathrm{o}, \mathrm{H}_{\mathrm{o}}$ : $\mathrm{x}$ dan y tidak berkorelasi $\mathrm{H}_{\mathrm{a}}$ : $\mathrm{x}$ dan y berkorelasi positif atau negatif. Jika $\rho>\rho$ tabel, $\mathrm{H}_{\mathrm{o}}$ ditolak dan $\mathrm{H}_{\mathrm{a}}$ diterima. Jika $\rho$ hitung $<=\rho$ tabel, $\mathrm{H}_{\mathrm{o}}$ diterima, $\mathrm{H}_{\mathrm{a}}$ ditolak. Sugiyono (1999) juga menjelaskan bahwa untuk penelitian yang dilakukan pada seluruh populasi, maka tidak diperlukan pengujian signifikansi terhadap koefisien korelasi yang ditemukan. Peneliti tidak perlu merumuskan dan menguji instrumen statistik.

\section{HASIL DAN PEMBAHASAN}

Melalui validasi data dan update data sitasi, diperoleh data yang semakin valid dan sah. Dari 4.295 data, terdapat 4.243 data yang sah, sedangkan 52 data dinyatakan tidak sah karena bukan merupakan publikasi Universitas Gadjah Mada, melainkan publikasi dari beberapa intitusi lain yang memiliki nama dan alamat institusi MADA, dan UGM.

\section{Sebaran Data}

Data publikasi Universitas Gadjah Mada sejumlah 4.243 tersebut memiliki sebaran dalam Tabel 2. 
Tabel 2 Sebaran Data Publikasi UGM 1954-2016

\begin{tabular}{|c|c|c|c|c|c|c|c|c|c|c|c|}
\hline Tahun & Pub & $\begin{array}{c}\mathrm{K}_{0} \\
\left(\begin{array}{lll}\mathrm{Nm} \\
)\end{array}\right.\end{array}$ & Int & Dom & Intl & $\begin{array}{c}\text { Ind ivi } \\
\text { (Ns) }\end{array}$ & Sitasi & $\begin{array}{c}\text { Sit } \\
\text { Indiv }\end{array}$ & $\begin{array}{l}\text { Sit } \\
\text { Int }\end{array}$ & $\begin{array}{c}\text { Sit } \\
\text { Dom }\end{array}$ & $\begin{array}{c}\text { Sit } \\
\text { Int }\end{array}$ \\
\hline 1954-195? & 4 & 1 & & & . & 3 & 26 & 2 & & & 24 \\
\hline 1960-1969 & 10 & 2 & & & 2 & 8 & 74 & 45 & & & 29 \\
\hline 1970-1979 & 33 & 23 & 16 & 1 & 6 & 10 & 201 & 63 & 83 & & 55 \\
\hline 1980-1989 & 91 & & 27 & & & & & 285 & 27 & & 541 \\
\hline 1990-1999 & 200 & 166 & 30 & 6 & 130 & 34 & 4139 & 325 & 125 & 93 & 3596 \\
\hline 2000-2009 & 682 & 637 & 71 & 50 & 516 & 45 & 12033 & 158 & 589 & 260 & 11026 \\
\hline 2010-2016 & 3223 & 3077 & 928 & 941 & 1208 & 146 & 9649 & 136 & 1248 & 1105 & 7160 \\
\hline mlah & 4243 & 3964 & 1072 & 998 & 1894 & 279 & 26975 & 1014 & 2072 & 1458 & 22431 \\
\hline
\end{tabular}

Dari tabel 2 di atas, terlihat bahwa terdapat perbedaan yang mencolok antara sitasi yang diperoleh dari karya kolaborasi internasional dengan karya individu dan karya kolaborasi lainnya.

\section{Sitasi Kolaborasi Internal, Domestik, Internasional Dan Individu}

Pengurutan bertingkat pada kolom kolaborasi dan kolom tahun, menghasilkan data jumlah sitasi yang diperoleh pada masingmasing jenis kolaborasi.

\section{Sitasi Kolaborasi Internal}

Publikasi kolaborasi internal berjumlah 1.072 judul, dengan perolehan sitasi sejumlah 2.072, sehingga dapat ditentukan rerata sebesar 1,9328 sitasi per publikasi.

\begin{tabular}{lr}
\multicolumn{2}{c}{ Tabel 3 Sitasi Kolaborasi Internal } \\
\hline Jumlah Publikasi & 4.243 \\
Jumlah publikasi kolaborasi internal & 1.072 \\
Prosentase publikasi kolaborasi & $25,2651 \%$ \\
internal & \\
Jumlah sitasi yang diperoleh & 2.072 \\
kolaborasi internal & \\
Rerata sitasi yang diperoleh & 1,9328 \\
kolaborasi internal & \\
\hline
\end{tabular}

Prosentase publikasi kolaborasi internal

$=(1.072 / 4.243) \times 100 \%$

$=25,2651 \%$

Rerata sitasi yang diperoleh kolaborasi internal $=2.072 / 1.072$

$=1,9328$ sitasi per publikasi

\section{Perkembangan Sitasi Kolaborasi Internal}

Sitasi kolaborasi internal diperoleh mulai dasawarsa 1970 sampai dengan 1979, kemudian mengalami penurunan pada dasawarsa 1980 sampai dengan 1989 seperti terlihat dalam grafik 1, dan mengalami kenaikan pada dasawarsa 1990 sd 1999 hingga 2010 sampai dengan 2016.

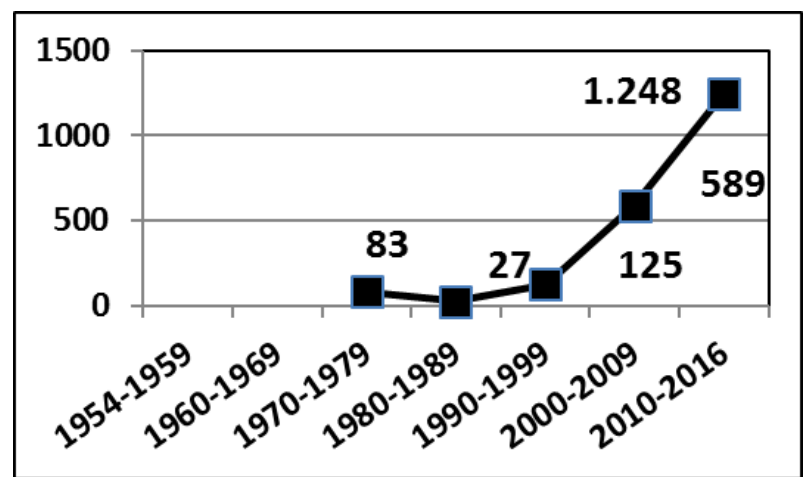

Grafik 1 Sitasi Kolaborasi Internal

\section{Sitasi Kolaborasi Domestik}

Publikasi kolaborasi domestik berjumlah 998 judul, dengan perolehan sitasi sejumlah 1.458, sehingga dapat ditentukan rerata sebesar 1,4609 sitasi per publikasi.

\begin{tabular}{lr}
\multicolumn{2}{c}{ Tabel 4 Sitasi Kolaborasi Domestik } \\
\hline Jumlah Publikasi & 4.243 \\
Jumlah publikasi kolaborasi domestik & 998 \\
Prosentase publikasi kolaborasi domestik & $23,5211 \%$ \\
$\begin{array}{l}\text { Jumlah sitasi yang diperoleh ko laborasi } \\
\text { domestik }\end{array}$ & 1.458 \\
$\begin{array}{l}\text { Rerata sitasi yang diperoleh kolaborasi } \\
\text { domestik }\end{array}$ & 1,4609 \\
\hline
\end{tabular}

Prosentase publikasi kolaborasi domestik

$=(998 / 4.243) \times 100 \%$

$=23,5211 \%$

Rerata sitasi yang diperoleh kolaborasi domestik $=1.458 / 998$

$$
=1,4609 \text { sitasi per publikasi }
$$

\section{Perkembangan Sitasi Kolaborasi Domestik}

Sitasi kolaborasi domestik mengalami peningkatan dari 1990 sd 1999 hingga 2010 sampai dengan 2016 seperti terlihat dalam grafik 2, sedangkan pada dasawarsa sebelumnya belum memperoleh sitasi.

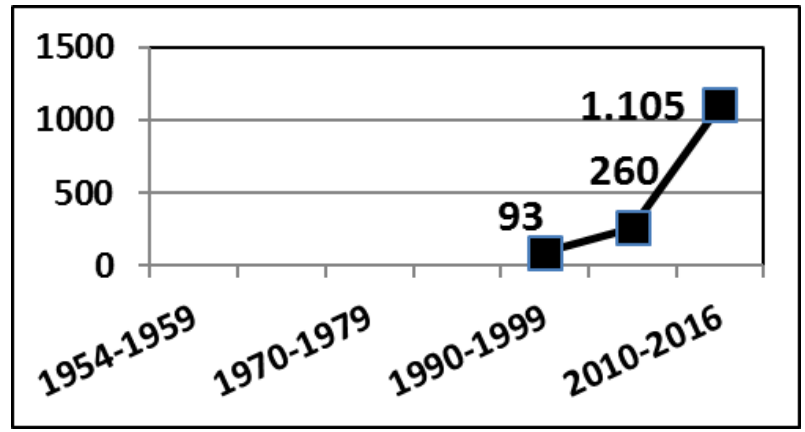

Grafik 2 Sitasi Kolaborasi Domestik 


\section{Sitasi Kolaborasi Internasional}

Publikasi kolaborasi internasional berjumlah 1.894 judul, dengan perolehan sitasi sejumlah 22.431, sehingga dapat ditentukan rerata sebesar 11,8432 sitasi per publikasi.

\begin{tabular}{lr}
\multicolumn{2}{c}{ Tabel 5 Sitasi Kolaborasi Interna sional } \\
\hline Jumlah Publikasi & $\mathbf{4 . 2 4 3}$ \\
Jumlah publikasi kolaborasi internasional & 1.894 \\
$\begin{array}{l}\text { Prosentase publikasi kolaborasi } \\
\text { internasional }\end{array}$ & $\mathbf{4 4 , 6 3 8 2 \%}$ \\
$\begin{array}{l}\text { Jumlah sitasi yang diperoleh kolaborasi } \\
\text { internasional }\end{array}$ & $\mathbf{2 2 . 4 3 1}$ \\
$\begin{array}{l}\text { Rerata sitasi yang diperoleh kolaborasi } \\
\text { internasional }\end{array}$ & $\mathbf{1 1 , 8 4 3 2}$ \\
\hline
\end{tabular}

Prosentase publikasi kolaborasi internasional

$=(1.894 / 4.243) \times 100 \%$

$=44,6382 \%$

Rerata sitasi yang diperoleh kolaborasi internasional $=22.431 / 1.894$

$$
=11,8432 \text { sitasi per publikasi }
$$

\section{Perkembangan Sitasi Kolaborasi Internasional}

Sitasi kolaborasi internasional cenderung meningkat dari tahun ke tahun, seperti terlihat dalam grafik 3 , hanya pada dasawarsa terakhir 2010 sd 2016 tercatat mengalami penurunan. Penurunan tersebut dapat dimaklumi, karena dasawarsa tersebut belum mencapai puncaknya, dan dapat diperkirakan bahwa saat mencapai puncaknya pada 2010-2019 akan mengalami peningkatan melebihi dasawarsa 2000-2009.

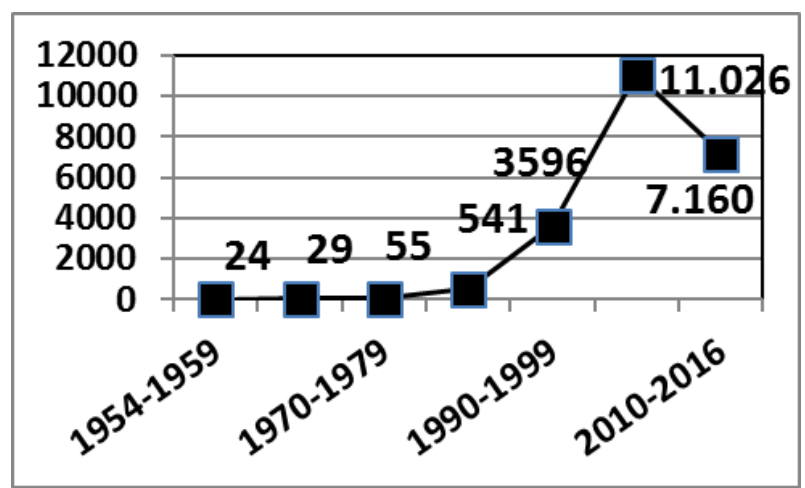

Grafik 3 Sitasi Kolaborasi Internasional

\section{Sitasi Publikasi karya individu}

Publikasi karya individu berjumlah 279 judul, dengan perolehan sitasi sejumlah 1.014, sehingga dapat ditentukan rerata sebesar 3,6344 sitasi per publikasi.

\begin{tabular}{lr}
\multicolumn{2}{c}{ Tabel 6 Sitasi Karya Individu } \\
\hline Jumlah Publikasi & 4.243 \\
Jumlah publikasi karya individu & 279 \\
Prosentase publikasi karya individu & $6,5755 \%$ \\
Jumlah sitasi yang diperoleh publikasi karya & 1.014 \\
$\begin{array}{l}\text { individu } \\
\text { Rerata sitasi yang diperoleh publikasi karya } \\
\text { individu }\end{array}$ & 3,6344 \\
\hline
\end{tabular}

Tabel 7 tersebut memperlihatkan jelas perbedaan perolehan sitasi yang mencolok antara kolaborasi internasional dibandingkan jenis kolaborasi lain dan karya individu. Perpaduan berbagai keahlian, berbagai bidang ilmu, berbagai jenis teknologi dan fasilitas riset antar beberapa negara terbukti menghasilkan publikasi dengan perolehan sitasi yang jauh lebih tinggi. Kolaborasi internasional menjadi prioritas untuk ditingkatkan dan dikembangkan untuk mendukung kinerja publikasi universitas.

\section{Korelasi Kolaborasi Penelitian dan Sitasi}

Analisis data korelasi menunjukkan hasil sebagai berikut:

\section{Korelasi Kolaborasi Internal dan Sitasi}

Perhitungan korelasi kolaborasi internal dan sitasi sebagai berikut:

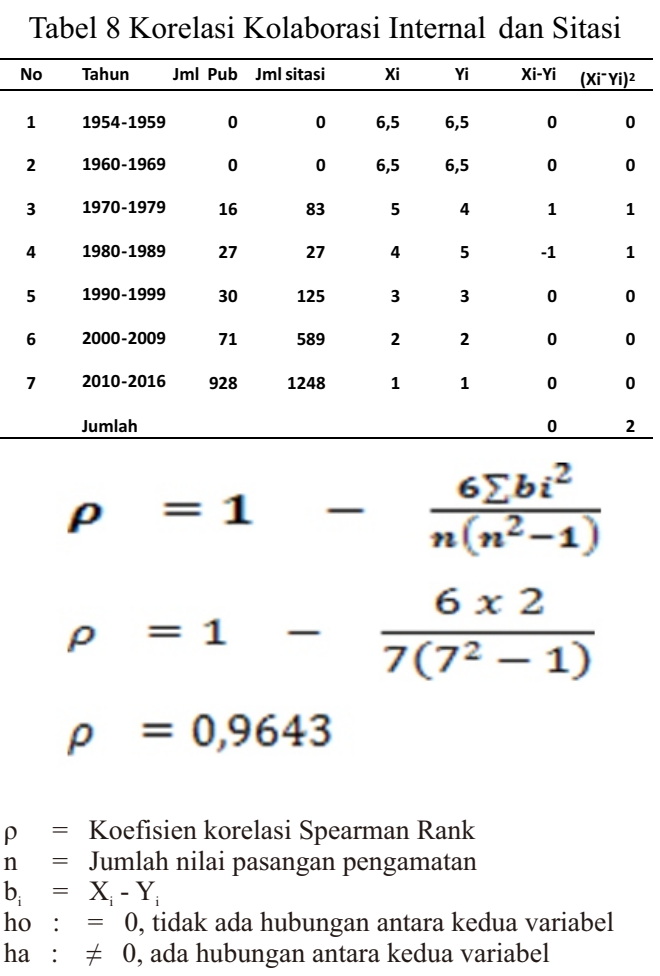


Menurut Sugiyono (1999: 302), tabel nilainilai $\rho$, untuk $\mathrm{n}=7$, dan untuk taraf signifikansi $5 \%$, nilai $\rho=0,786$, sedangkan untuk $1 \%$ nilai $\rho$ $=0,929$. Berdasarkan perhitungan di atas, $\rho$ hitung $>\rho$ tabel, sehingga dapat disimpulkan bahwa $\mathrm{h}_{0}$ ditolak, $\mathrm{h}_{\mathrm{a}}$ diterima. Terdapat hubungan (korelasi) antara Jumlah publikasi karya kolaborasi internal dengan jumlah sitasi.

\section{Korelasi Kolaborasi Domestik dan Sitasi}

Perhitungan korelasi kolaborasi domestik dan sitasi sebagai berikut:

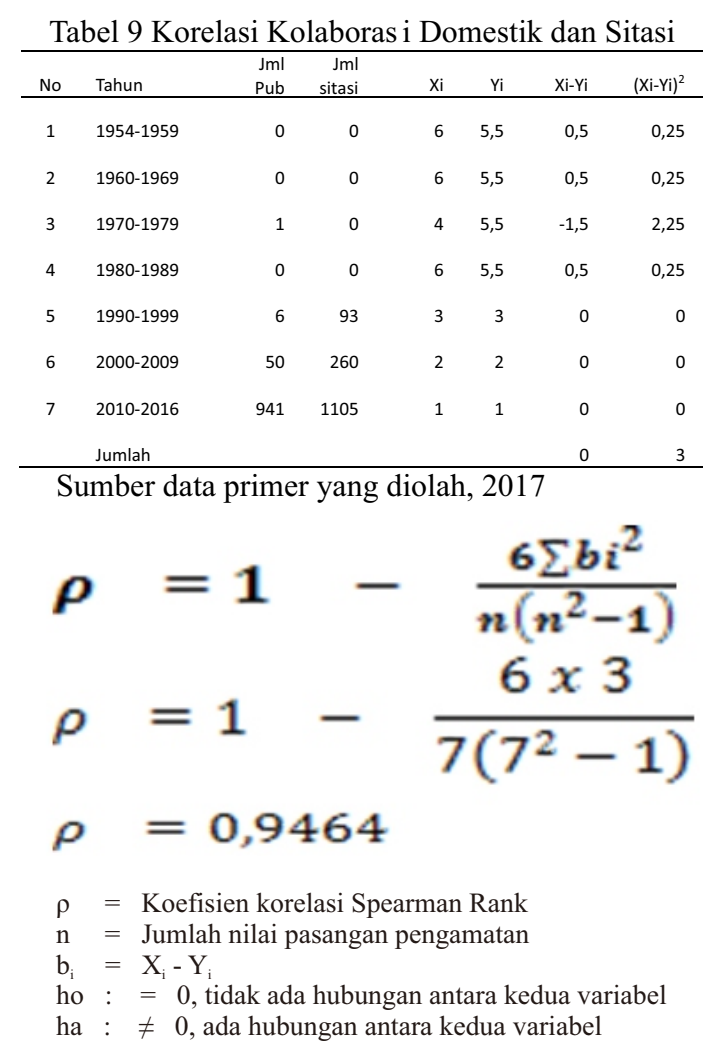

Menurut Sugiyono (1999: 302), tabel nilainilai $\rho$, untuk $n=7$, dan untuk taraf signifikansi $5 \%$, nilai $\rho=0,786$, sedangkan untuk $1 \%$ nilai $\rho$ $=0,929$. Berdasarkan perhitungan di atas, $\rho$ hitung $>\rho$ tabel, sehingga dapat disimpulkan bahwa $\mathrm{h}_{0}$ ditolak, $\mathrm{h}_{\mathrm{a}}$ diterima. Terdapat hubungan (korelasi) antara Jumlah publikasi karya kolaborasi domestik dengan jumlah sitasi.
Korelasi Kolaborasi Internasional Dan Sitasi

Perhitungan korelasi kolaborasi internasional dan sitasi sebagai berikut:

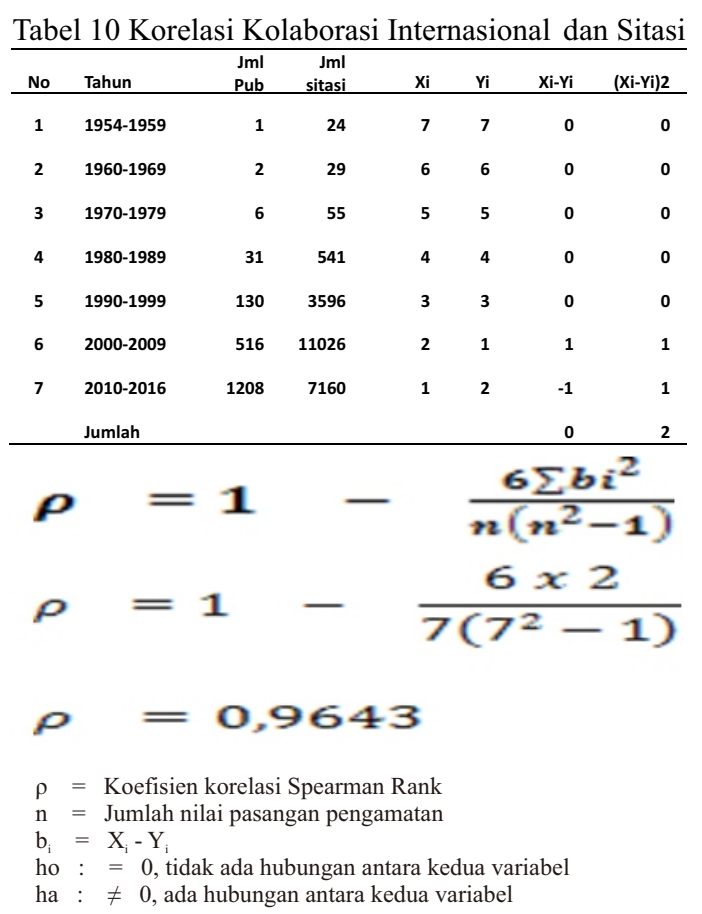

Menurut Sugiyono (1999: 302), tabel nilainilai $\rho$, untuk $\mathrm{n}=7$, dan untuk taraf signifikansi $5 \%$, nilai $\rho=0,786$, sedangkan untuk $1 \%$ nilai $\rho$ $=0,929$. Berdasarkan perhitungan di atas, $\rho$ hitung $>\rho$ tabel, sehingga dapat disimpulkan bahwa $\mathrm{h}_{0}$ ditolak, $\mathrm{h}_{\mathrm{a}}$ diterima. Terdapat hubungan (korelasi) antara Jumlah publikasi karya kolaborasi internasional dengan jumlah sitasi.

Tabel 30 di atas menunjukan bahwa pada dasawarsa 2010-2016 yang sedang berjalan, jumlah sitasi yang diperoleh belum mencapai puncaknya, lebih rendah dari dasawarsa sebelumnya 2000-2009. Dapat diperkirakan bahwa pada saat dasawarsa 2010-2019 berakhir, jumlah sitasi mencapai puncaknya pada tahun 2017-2019, dan terjadi hubungan positif sempurna antara jumlah publikasi karya kolaborasi internasional dengan sitasi yang diperoleh dengan angka korelasi sebesar +1 . 


\section{Korelasi Publikasi Individu dan Sitasi}

Perhitungan korelasi karya individu dan sitasi sebagai berikut:

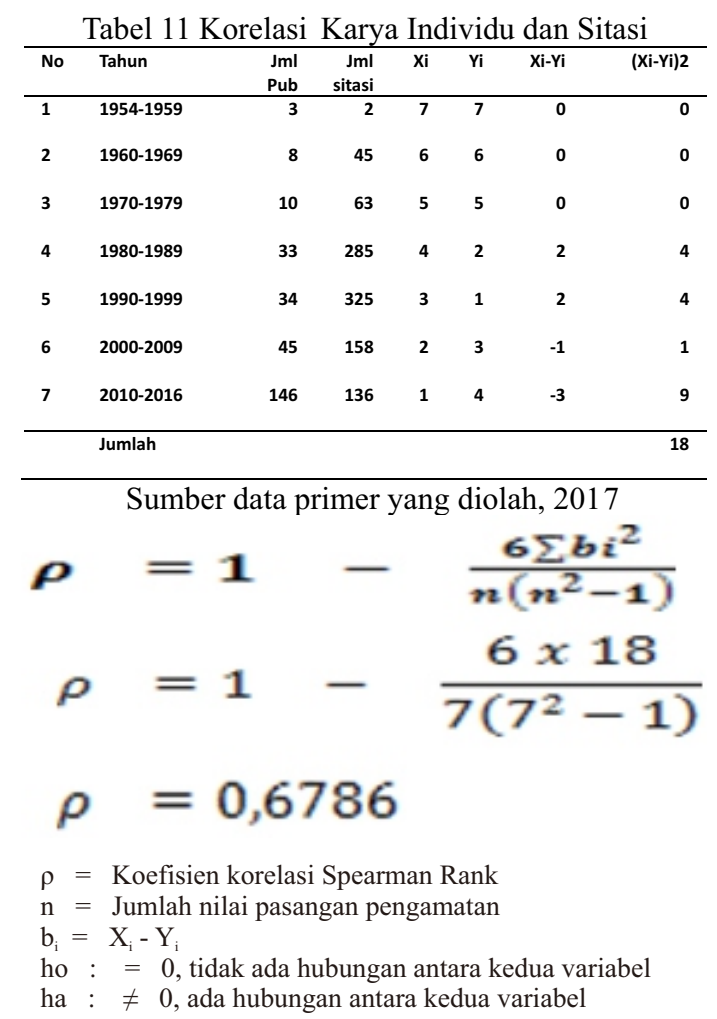

Menurut Sugiyono (1999: 302), tabel nilainilai $\rho$, untuk $\mathrm{n}=7$, dan untuk taraf signifikansi $5 \%$, nilai $\rho=0,786$, sedangkan untuk $1 \%$ nilai $\rho$ $=0,929$. Berdasarkan perhitungan di atas, $\rho$ hitung $<\rho$ tabel, sehingga dapat disimpulkan bahwa $h_{0}$ diterima, $h_{a}$ ditolak. Tidak terdapat hubungan (korelasi) antara jumlah publikasi karya individu dengan jumlah sitasi.

\section{Perbandingan Korelasi Berbagai Kolaborasi dan Sitasi}

Perhitungan korelasi berbagai kolaborasi dan sitasi menghasilkan kesimpulan dalam tabel 12 berikut:

Tabel 12 Korelasi Kolaborasi dan Sitasi

\begin{tabular}{|c|c|c|}
\hline $\begin{array}{l}\text { Korelasi Kolaborasi internal } \\
\text { dan Sitasi }\end{array}$ & $\begin{array}{l}\rho \text { hitung } 0,9643 \\
>\rho \text { tabel }\end{array}$ & $\begin{array}{l}\text { Terdapat } \\
\text { korelasi positif }\end{array}$ \\
\hline $\begin{array}{l}\text { Korelasi Kolaborasi } \\
\text { domestik dan Sitasi }\end{array}$ & $\begin{array}{l}\rho \text { hitung } 0,9464 \\
>\rho \text { tabel }\end{array}$ & $\begin{array}{l}\text { Terdapat } \\
\text { korelasi positif }\end{array}$ \\
\hline $\begin{array}{l}\text { Korelasi Kolaborasi } \\
\text { internasional dan Sitasi }\end{array}$ & $\begin{array}{l}\rho \text { hitung } 0,9643 \\
>\rho \text { tabel }\end{array}$ & $\begin{array}{l}\text { Terdapat } \\
\text { korelasi positif }\end{array}$ \\
\hline $\begin{array}{l}\text { Korelasi publikasi individu } \\
\text { dan Sitasi }\end{array}$ & $\begin{array}{l}\rho \text { hitung } 0,6786 \\
<\rho \text { tabel }\end{array}$ & $\begin{array}{l}\text { Tidak terdapat } \\
\text { korelasi }\end{array}$ \\
\hline
\end{tabular}

Sumber data primer yang diolah, 2017
Data tersebut di atas menunjukkan bahwa semua jenis kolaborasi berkorelasi positif dengan sitasi yang diperoleh. Sedangkan publikasi karya individu tidak terdapat korelasi dengan sitasi yang diperoleh. Meskipun semua jenis kolaborasi berkorelasi positif dengan sitasi yang diperoleh, tetapi kolaborasi internasional dapat diperkirakan akan berkorelasi sempurna +1 pada saat dasawarsa 2010-2019 berakhir seiring bertambahnya perolehan sitasi pada tahun 2017-2019.

\section{Negara Kolaborator Memperoleh Sitasi Tertinggi}

Sebanyak 85 negara telah berkolaborasi dengan peneliti berafiliasi UGM, dan 15 negara kolaborator utama yang memperoleh sitasi tertinggi yaitu: Jepang sejumlah 5.242 sitasi, USA 4.503 sitasi, Netherlands 4.057 sitasi, Australia 2.966 sitasi, Malaysia 2.296 sitasi, Germany 2056 sitasi, UK 1866 sitasi, France 1548 sitasi, Switzerland 1491 sitasi, China 1172 sitasi, Philippines 1141 sitasi, India 1105 sitasi, Sweden 1074 sitasi, Singapore 1040 sitasi, dan Thailand 1007 sitasi. Kelimabelas negara tersebut semuanya menghasilkan perolehan sitasi di atas 1000 sitasi. Peringkat negara kolaborator memperoleh sitasi tertertinggi divisualisasikan dalam grafik 5 berikut:

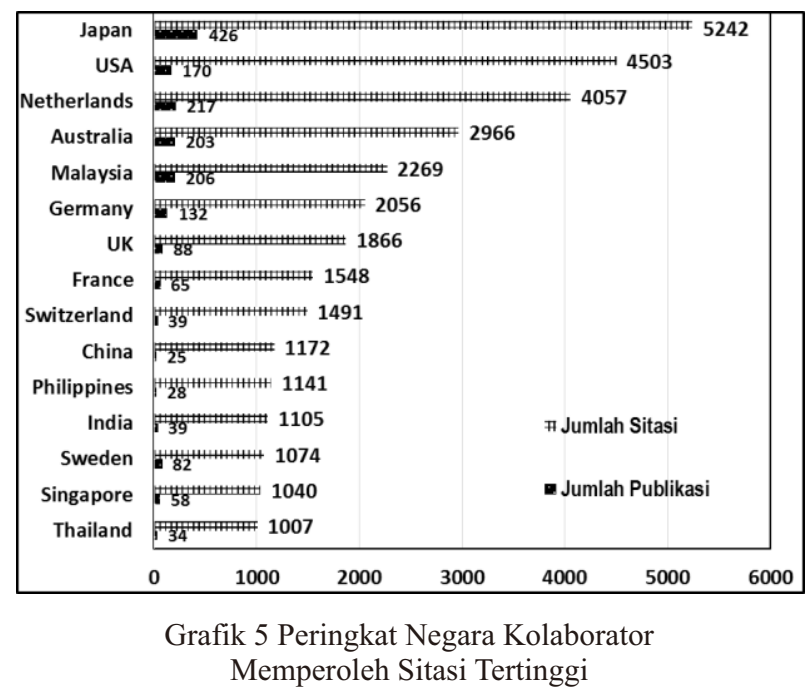


Dengan melihat hasil positif tersebut, kerjasama kolaborasi riset dan publikasi UGM dapat diarahkan dan ditingkatkan dengan menjalin kolaborasi bersama peneliti dari negara-negara tersebut. Sebagaimana diketahui bahwa pemeringkatan universitas (university rankings) yaitu QS Quacquarelli Symonds World University rankings mempergunakan data sitasi Scopus sebagai dasar penilaian dan diberi bobot nilai sebesar 20\%. Sedangkan ARWU (Academic Ranking of World Universities) mempergunakan data sitasi dari Web of Science. Perolehan sitasi yang tinggi jelas akan mendongkrak posisi universitas dalam pemeringkatan.

\section{E. KESIMPULAN}

Kolaborasi internasional menghasilkan sitasi jauh lebih banyak dibandingkan kolaborasi lain dan karya individu. Sitasi kolaborasi internasional sejumlah 22.431, dengan rerata 11,8432 . Sitasi kolaborasi internal sejumlah 2.072, dengan rerata 1,9328. Sitasi kolaborasi domestik sejumlah 1.458, dengan rerata 1,4609 . Sitasi karya individu sejumlah 1.014, dengan rerata 3,6344.

Semua publikasi karya kolaborasi berkorelasi positif dengan sitasi yang diperoleh. Korelasi publikasi karya kolaborasi internal sebesar 0,9643, domestik sebesar 0,9464, dan internasional sebesar 0,9643. Sedangkan publikasi karya individu sebesar 0,6786 tidak berkorelasi dengan sitasi yang diperoleh. Kolaborasi internasional diperkirakan akan memiliki korelasi sempurna sebesar +1 pada akhir dasawarsa seiring pertambahan jumlah sitasi yang diperoleh pada akhir dasawarsa yaitu tahun 2017-2019.

Sebanyak 85 negara telah berkolaborasi dengan peneliti UGM, dan 15 negara kolaborator utama yang memperoleh sitasi tertinggi yaitu: Jepang sejumlah 5.242 sitasi, USA 4.503 sitasi, Netherlands 4.057 sitasi, Australia 2.966 sitasi, Malaysia 2.296 sitasi, Germany 2056 sitasi, UK 1866 sitasi, France 1548 sitasi, Switzerland 1491 sitasi, China 1172 sitasi, Philippines 1141 sitasi, India 1105 sitasi, Sweden 1074 sitasi, Singapore 1040 sitasi, dan
Thailand 1007 sitasi. Kelimabelas negara tersebut semuanya menghasilkan perolehan sitasi di atas 1000 sitasi.

\section{DAFTAR PUSTAKA}

ARWU Academic Ranking of World Universities. (2016). About Academic Ranking of World Universities. http://www.shanghairanking.com/ aboutarwu.html

Beaver, D. Deb. (2001). Reflections on scientific collaboration (and its study): past, present, and future. Scientometrics, 52 (3), p. $365-377$. https://doi.org/ 10.1023/A:1014254214337

Chadegani, Arezoo Aghaei dkk., (2013). A Comparison between Two Main Academic Literature Collections: Web of Science and Scopus Databases. Asian Social Science; Vol. 9, No. 5, p.18-26. DOI: http://dx.doi.org/10.5539/ass.v9n5p18

Cainelli, Giulio dkk. (2015). The strength of strong ties: How co-authorship affect productivity of academic economists?. Scientometrics 102:673-699. DOI 10.1007/s11192-014-1421-5

Dikti. (2017). Pangkalan Data Pendidikan Tinggi Kementerian Riset, Teknologi Dan $\mathrm{P}$ e $\mathrm{n} \mathrm{d} \mathrm{i} \mathrm{d} \mathrm{i} \mathrm{k} \mathrm{a} \quad T$ i n g g i . http://forlap.dikti.go.id/perguruantinggi/ search/4480. Diunduh 13 Maret 2017

$\mathrm{Hu}$, Zhigang dkk. (2014). How are collaboration and productivity correlated at various career stages of scientists? Scientometrics 101:1553-1564. DOI 10.1007/s11192-014-1323-6

Ibanez, Alfonso., dkk. (2013). Relationship among research collaboration, number of documents and number of citations: a case study in Spanish computer science production in 2000-2009. Scientometrics 95:689-716. DOI 10.1007/s11192-0120883-6

International encyclopedia of information and library science. $2^{\text {nd }}$ ed. 2003. London: Routledge 
Katz, J. Sylvan dan Ben R. Martin. (1997). What is research collaboration ? Research Policy 26 (1997) 1-18. https://doi.org/10.1016/ S0048-7333(96)00917-1

Kim, Hyungsun. (2015)., How to index journal in Scopus \& WoS. The 2nd Asian Science Editors' Conference \& Workshop Hanoi University of Science and Technology Hanoi, Vietnam August 20-22, , diunduh 29 Maret 2017

Lampiran Peraturan Menteri Riset, Teknologi, dan Pendidikan Tinggi Nomor 20 Tahun 2017 Tentang Pemberian Tunjangan Profesi Dosen dan Tunjangan Kehormatan Profesor

Murti, Bhisma. (1996). Penerapam Metode Statistik Non-Parametrik Dalam Ilmu-ilmu Kesehatan. Jakarta: Gramedia Pustaka Utama

Nguyen, Tuan V. dkk. (2017). International collaboration in scientific research in Vietnam: an analysis of patterns and impact. Scientometrics 110:1035-1051. DOI 10.1007/s11192-016-2201-1

Peraturan Menteri Pendidikan Dan Kebudayaan Republik Indonesia Nomor 92 Tahun 2014 Tentang Petunjuk Teknis Pelaksanaan Penilaian Angka Kredit Jabatan Fungsional Dosen

Peraturan Kepala Lembaga Ilmu Pengetahuan Indonesia Nomor 9 Tahun 2015 Tentang Profesor Riset

Prihanto, Igif G. (2002). Kolaborasi. Dalam Kumpulan Makalah Kursus Bibliometrika. Jakarta : Masyarakat Informetrika Indonesia

QS World University Rankings. (2017). QS World University Rankings Methodology. https://www.topuniversities.com/qs-worlduniversity-rankings/methodology

Sangam, Shivappa L. (2000). Collaborative Research in Psychology in India:

A Scientometric Study. Collaboration in Science and in Technology Proceedings of the Second Berlin Workshop on Scientometrics and Informetrics September 1 - 3, 2000. pp.177-183, , diunduh 29 Maret 2017
Scimago. (2017). Scimago Journal \& Country Rank. http://www.scimagojr.com/ countryrank.php. Diunduh 13 Maret 2017

Scopus., (2017). Scopus advanced search. https://www.scopus.com/results/, diunduh 23 Maret 2017

Servellen, A lexander van. (2016). ScopusTraining for Universitas Gadjah Mada, August 31st, 2016

Sooryamoorthy, Radhamany. (2017). Do types of collaboration change citation? A scientometric analysis of social science publications in South Africa. Scientometrics, p p 1-22. doi:10.1007/s11192-017-2265-6

Sugiyono. (1999). Statistika Untuk Penelitian. Bandung: Alfabeta

Sulistyo-Basuki. (2002). Bibliometrika, Sainsmetrika, dan Informetrika. Dalam Kumpulan Makalah Kursus Bibliometrika. Jakarta : Masyarakat Informetrika Indonesia

Surat Edaran Dirjen Dikti No.152/E/T/2013 tanggal 27 Januari 2012 Tentang Ketentuan publikasi untuk program $\mathrm{S} 1 / \mathrm{S} 2 / \mathrm{S} 3$

Wagner, A. Ben. (2015). A Practical Comparison Of Scopus And Web

Of Science Core Collection. Upstate New York Science Librarians Conference. 10/23/2015. Paper 70. http://surface.syr.edu/nyscilib/70 diunduh 29 Maret 2017

Web of Science. (2017). Web of Science realfacts. http://wokinfo.com/ citationconnection/realfacts/, diunduh 14 Maret 2017

Wulandari, Srividola. (2013). Analisis Kolaborasi Peneliti Berdasarkan Disiplin Ilmu Dalam Penelitian Institut Pertanian Bogor Dengan Pendekatan Bibliometrik. (skripsi). Bogor: FMIPA IPB. http://repository.ipb.ac.id/handle/ $\underline{123456789 / 65323}$ 